\title{
Challenges in the Pharmacological Management of Non Hodgkin's Lymphoma in Children in the Maintenance Phase of Therapy at Kenyatta National Hospital
}

\author{
Mwangi WW ${ }^{* 1,2}$, Karimi $\mathrm{P}^{1}$, Githinji $\mathrm{C}^{1}$ and Fatmah $\mathrm{A}^{3}$ \\ ${ }^{1}$ School of Pharmacy University of Nairobi, Nairobi, Kenya \\ ${ }^{2}$ Ministry of health, Nairobi, Kenya \\ ${ }^{3}$ School of Medicine University of Nairobi, Kenya
}

${ }^{*}$ Corresponding author: Mwangi WW, School of Pharmacy University of Nairobi, Nairobi, Kenya, Tel: 254722436580, E-mail: winniewanjikum@gmail.com

Citation: Mwangi WW, Karimi P, Githinji C, Fatmah A (2016) Challenges in the Pharmacological Management of Non Hodgkin's Lymphoma in Children in the Maintenance Phase of Therapy at Kenyatta National Hospital. J Cancer Sci Clin Oncol 3(2): 207. doi: 10.15744/2394-6520.3.207

Received Date: June 03, 2016 Accepted Date: September 19, 2016 Published Date: September 23, 2016

\begin{abstract}
Background: Non Hodgkin's lymphoma is an extremely chemo sensitive with a five year event free survival of greater than $90 \%$ in developed countries and a one year survival rate of 40-50\% in developing countries. There have been no documented studies done at Kenyatta National Hospital on the various challenges faced by patients and their guardians that may hinder its optimal management.

Objectives: To investigate the major challenges faced in the management of Non Hodgkin's lymphoma in pediatric patients in the maintenance phase.

Methodology: This was a hospital based cross-sectional study, among 19 Paediatric outpatients with Non Hodgkin's Lymphoma and in the maintenance phase of therapy at Kenyatta National Hospital. Data was collected using structured questionnaires and from patient files and was analyzed using Statistical Package for Social Sciences version 17.0. P values $\leq 0.05$ were considered significant. Fischer's exact test was used to test for association between adherence and various categorical variables such as patient factors, guardian factors and hospital and service delivery setup.

Results: Of the 19 patients, 13 (68.4\%) were found to be male. The mean age for all the patients was 9.84 years (95\% CI: 8.3, 11.3). $42.1 \%$ of the patients had missed their oral medication. The method of acquisition of oral medication, estimated expenditure on medication per month and whether the guardian was counseled on the side effects of the medication, were found to be statistically significant ( $\mathrm{p}$ value $0.037,0.02$ and 0.037 respectively). The most prevalent $(94.7 \%$ ) side effects were loss of hair followed by change in nail/skin pigmentation $(73.7 \%)$ with the least observed side effects being dizziness, constipation and tingling sensation of lower extremities. Cumulative doses of doxorubicin used showed that majority of the patients (63.1\%) had cumulative doses between 200 $400 \mathrm{mg} / \mathrm{m}^{2}$ while only $10 \%$ had cumulative doses above $400 \mathrm{mg} / \mathrm{m}^{2}$.

Conclusion: The overall adherence to oral chemotherapy was found to be $57.9 \%$. Method of acquisition of the oral medication, estimated expenditure on medication per month and counseling on medication and its side effects were significant barriers to adherence. Based on cumulative doses of doxorubicin used, $63.1 \%$ of the patients in this study stand a low risk of developing cardio toxicity with only $10 \%$ standing a significant risk of cardio toxicity.
\end{abstract}

Keywords: Non Hodgkin’s Lymphoma; Oral Chemotherapy; Adherence; Side Effects; Cumulative Doses

\section{Introduction}

Non Hodgkin's lymphoma (NHL) is a group of related malignancies of the lymphatic system [1]. Some of the Non Hodgkin's lymphoma are among the most rapid growing and aggressive of all cancers while others are indolent.

There are three main types of Non Hodgkin's lymphoma in children and they include lymphoblastic lymphoma, small non cleaved cell lymphoma and large cell lymphoma all of which $90 \%$ of the time have been classified as high grade disease compared to adults [1].

Small non cleaved cell lymphoma (Burkitt's lymphoma) represents over half of childhood cancers in equatorial Africa and in Kenya a study done by Cool, et al. showed that majority of the NHL cases were of the B cell lineage with Burkitt's lymphoma being the most common followed by diffuse large B cell lymphoma [2]. Burkitt's lymphoma has been shown to be mainly a childhood tumor and accounts for up to $36 \%$ of childhood cancers and $70 \%$ of childhood lymphomas in sub-Saharan Africa [3]. 
It has been proven that most types of Non Hodgkin's lymphoma in particular Burkitt's lymphoma are curable with long term survival rates [4]. However, various factors in most developing countries have made this unachievable for example cost of medication and services offered in the management of Burkitt's lymphoma which varies from 450 US dollars to 2800 US dollars whereas income of the majority of the population in most developing countries is less than 1 US dollar per day $[5,6]$. The education level of the caregivers, side effects of the medication, social and cultural factors as well as counseling of caregivers have also been shown to hinder optimal management of Non Hodgkin's lymphoma [7]. So far there have been no documented studies done in $\mathrm{KNH}$ on the various challenges faced by patients and guardians during the management of Non Hodgkin's lymphoma and any other factors that may hinder its optimal management.

Therefore the objective of this study was to investigate the major challenges faced in the management of Non Hodgkin's lymphoma in pediatric patients in the maintenance phase. This was done by investigating the factors that affect adherence to oral chemotherapy, prevalence of side effects, assessing the guardians knowledge on the disease and its management and determination of patients with appropriate drug use and cumulative doses of doxorubicin used.

\section{Methodology}

\section{Study design}

The study conducted was a hospital based cross-sectional study

\section{Study area}

This study was carried out at the Kenyatta National Hospital (KNH) pediatric haematology outpatient clinic 23 between $19^{\text {th }}$ July, 2013 and $28^{\text {th }}$ October 2013. KNH is the largest teaching and referral hospital in east and central Africa and serves as the main referral for most pediatric cancer patients in the country.

\section{Target population}

Pediatric patients attending the pediatric outpatient clinic that had been diagnosed with Non Hodgkin's lymphoma and were in the maintenance phase of therapy [8].

\section{Inclusion and Exclusion criteria}

The patients that were included in the study were pediatric patients being managed for Non Hodgkin's lymphoma in the maintenance phase of therapy and were using 6Mercaptopurine, Methotrexate, Vincristine, Adriamycin and Cyclophosphamide.

Patients who were on any other drug regimens, were below two years of age and had any other co-morbidities were excluded from the study.

\section{Sample size determination and sampling procedure}

The sample size was calculated using the Fischer's formula. The desired sample size was 37 patients. The patients were first identified by going through the patient files delivered at the clinic and selecting those that met the inclusion criteria. A final study sample of 19 patients was used.

\section{Data collection}

Data was collected by filling in the questionnaire by the principal investigator by holding face to face interviews with the guardians to the patients after informed consent. The guardians were interviewed to determine adherence to oral chemotherapy, knowledge on the disease, medication and its side effects and appropriate drug use. The files to the same patients were perused for side effects due to medication, confirmation on appropriate drug use for parenteral medication and cumulative doses of doxorubicin used.

Adherence was measured by determining number of prescribed oral chemotherapy taken in the last two weeks.

\section{Quality Assurance}

\section{Pilot Study}

A pilot study was done by randomly selecting 5 study subjects. The shortcomings were detected and were used to improve the data collection instrument.

\section{Validity}

Internal validity was ensured by using simplified language in the questions asked which were geared towards the study objectives. Adherence was further validated by using a two week recall period as opposed to one month to avoid recall bias. 


\section{Ethical Considerations}

Approval to carry out the study was obtained from the Kenyatta National Hospital/ University of Nairobi Ethics and Research Committee (KNH/UON ERC). Approval was granted as per letter of reference Number KNH-ERC/A/190 dated $5^{\text {th }}$ July 2013. Patients' names did not appear on the data collection forms and instead serial numbers were used. The data collection materials were kept under lock and key during the entire study time.

\section{Data Analysis}

Data was analyzed using SPSS version 17.0. Numerical data was summarized as means. Mann-Whitney test was used to test for difference in medians values for the continuous variables among those children who were adhering to oral treatment against those who were not adhering. Additionally their mean values were computed with the accompanying 95\% confidence intervals. Categorical data was summarized in percentages and graph form. To test for association between adherence and various categorical variables Fisher's exact test was used. Variables were cross tabulated to assess factors that contribute to adherence to oral medication. P-values of less than 0.05 were considered significant.

\section{Results}

\section{Baseline characteristics of the patients}

The baseline characteristic of the 19 patients is shown in Table 1. Most (68.4\%) of the patients were male ( $\mathrm{n}=13)$. The mean age of the patients was 9.84 years with a minimum of 4 years and a maximum of 13 years.

\begin{tabular}{|c|c|c|}
\hline Variable & $\begin{array}{c}\text { Frequency } \\
(\mathbf{N}=19)\end{array}$ & $\%$ \\
\hline Female & 6 & 31.6 \\
\hline Male & 13 & 68.4 \\
\hline \multicolumn{3}{|c|}{ BMI } \\
\hline Ideal & 14 & $73.7 \%$ \\
\hline Underweight & 3 & $15.8 \%$ \\
\hline Overweight & 2 & $10.5 \%$ \\
\hline \multicolumn{3}{|c|}{4} \\
\hline MGE & $9.82(95 \%$ CI:8.3, 11.3$)$ \\
\hline Minimum & \multicolumn{2}{|c|}{43} \\
\hline Maximum &
\end{tabular}

Table 1: Patient baseline characteristics

\section{Characteristics of the guardians}

Most (84.2\%) of the guardians to the patients were married with majority being unemployed. Majority of the spouses to the guardians were self employed at 50\%. The average monthly income was found to be between Ksh 0-9,999 (US \$0-99).

$31.6 \%$ of the guardians had primary school education while the majority (47.4\%) had secondary school education a small number of patients had tertiary education or no education at all. This is as shown in Table 2.

\begin{tabular}{|c|c|c|}
\hline Variable & $\begin{array}{c}\text { Frequency } \\
\qquad(\mathrm{N}=19)\end{array}$ & $\%$ \\
\hline \multicolumn{3}{|c|}{ Marital status } \\
\hline Single & 3 & 15.8 \\
\hline Married & 16 & 84.2 \\
\hline \multicolumn{3}{|c|}{ Employment status } \\
\hline Employed & 0 & 0 \\
\hline Self Employed & 7 & 36.8 \\
\hline Unemployed & 12 & 63.2 \\
\hline \multicolumn{3}{|c|}{ Spouse employment status $(n=16)$} \\
\hline Employed & 6 & 37.5 \\
\hline Self Employed & 8 & 50.0 \\
\hline Unemployed & 2 & 12.5 \\
\hline
\end{tabular}




\begin{tabular}{|c|c|c|}
\hline Variable & $\begin{array}{c}\text { Frequency } \\
(\mathbf{N}=19)\end{array}$ & $\%$ \\
\hline \multicolumn{2}{|c|}{ Average Monthly income } \\
\hline $\mathbf{0 - 9 , 9 9 9}$ & 13 & 68.4 \\
\hline $\mathbf{1 0 , 0 0 0 - 2 9 , 9 9 9}$ & 4 & 21.1 \\
\hline $\mathbf{3 0 , 0 0 0 - 4 9 , 9 9 9}$ & 2 & 10.5 \\
\hline \multicolumn{2}{|c|}{ Education Level } \\
\hline Primary & 6 & 31.6 \\
\hline Secondary & 9 & 47.4 \\
\hline Tertiary & 2 & 10.5 \\
\hline Others & 2 & 10.5 \\
\hline
\end{tabular}

Table 2: Information on the guardian

\section{Knowledge assessment}

Most of the guardians claimed on knowing what their children were being managed for and the response on the explanations they gave were graded as either:

Not informed - if they gave the wrong information or no information on the disease

Fairly informed- if they gave correct but limited information on the disease

Well informed- If they gave correct and comprehensive information on the disease

The major source of information for the guardians on the disease was from a health care provider with $52.6 \%$ being fairly informed and approximately $20 \%$ being well informed or not informed.

Majority of the patients had never had any counselling on side effects of the medication with only $42.1 \%$ being counselled on side effects most (62,5\%) of which was done by a nurse.

Loss of hair, vomiting and changes in skin or nail pigmentation were considered as side effects of medication by most of the guardians while none of them considered constipation as a side effect as shown in Table 3.

\begin{tabular}{|c|c|c|}
\hline Variable & Frequency & $\%$ \\
\hline \multicolumn{3}{|c|}{ Knows what your child is being treated for } \\
\hline Yes & 18 & 94.7 \\
\hline No & 1 & 5.3 \\
\hline \multicolumn{3}{|c|}{ Explanation on what the child is being treated for } \\
\hline Not informed & 4 & 21.1 \\
\hline Fairly informed & 10 & 52.6 \\
\hline Well informed & 5 & 26.3 \\
\hline \multicolumn{3}{|c|}{ Information source $(n=18)$} \\
\hline Health provider & 18 & $100 \%$ \\
\hline \multicolumn{3}{|c|}{ Aware of the medication your child is taking } \\
\hline Yes & 17 & 89.5 \\
\hline No & 2 & 10.5 \\
\hline \multicolumn{3}{|c|}{ Correct knowledge on medicine duration } \\
\hline Yes & 17 & 89.5 \\
\hline No & 2 & 10.5 \\
\hline \multicolumn{3}{|c|}{ counseled on side effects of the medication } \\
\hline Yes & 8 & 42.1 \\
\hline No & 11 & 57.9 \\
\hline \multicolumn{3}{|c|}{ Counseled by whom } \\
\hline Clinician & 3 & 37.5 \\
\hline Nurse & 5 & 62.5 \\
\hline \multicolumn{3}{|c|}{$\begin{array}{l}\text { Proportions that considers the following as } \\
\text { possible side effects of the drugs }\end{array}$} \\
\hline Vomiting & 17 & 89.5 \\
\hline
\end{tabular}




\begin{tabular}{|c|c|c|}
\hline Variable & Frequency & $\%$ \\
\hline \multicolumn{2}{|c|}{$\begin{array}{c}\text { Proportions that considers the following as } \\
\text { possible side effects of the drugs }\end{array}$} \\
\hline Diarrhea & 3 & 15.8 \\
\hline Lack of appetite & 8 & 42.1 \\
\hline Constipation & 0 & 0 \\
\hline Loss of hair & 18 & 94.7 \\
\hline $\begin{array}{c}\text { Darkening of the } \\
\text { skin }\end{array}$ & 13 & 68.4 \\
\hline $\begin{array}{c}\text { Signs of } \\
\text { Myelosuppression }\end{array}$ & 5 & 26.3 \\
\hline
\end{tabular}

Table 3: Knowledge assessment

\section{Factors affecting adherence}

Adherence to oral chemotherapy was determined using self report from the patients' guardians. Adherence was taken to mean having taken all prescribed oral chemotherapy in the last two weeks while non adherence was taken to mean having missed any doses of oral chemotherapy in the last two weeks.

$42.1 \%(n=8)$ of the patients had missed their oral medication in the last two weeks with a majority (50\%) having missed because the guardians could not afford to buy the medication followed by those who could not find the drug (25\%).

Acquisition of oral medication for most of the patients (57.9\%) was by buying using their own cash. The estimated expenditure per month for the oral medication was found to be between ksh 6,500 (US \$65) and ksh 25,000 (US 250) with a mean of ksh 11,321 (US \$113.21) (Table 4).

\begin{tabular}{|c|c|c|}
\hline Variable & Frequency & $\%$ \\
\hline \multicolumn{3}{|c|}{ Medication source-Injectable } \\
\hline Hospital pharmacy & 19 & 100 \\
\hline \multicolumn{3}{|c|}{ Medication source-orals } \\
\hline Hospital pharmacy & 5 & 26.3 \\
\hline Private pharmacy & 14 & 73.7 \\
\hline \multicolumn{3}{|c|}{ How they acquire orals medications } \\
\hline Buys cash & 11 & 57.9 \\
\hline $\begin{array}{l}\text { Buys cash with some } \\
\text { of it donated }\end{array}$ & 3 & 15.8 \\
\hline Pay by insurance & 4 & 21.1 \\
\hline $\begin{array}{c}\text { Pays by insurance } \\
\text { and some are cash } \\
\text { donated }\end{array}$ & 1 & 5.3 \\
\hline \multicolumn{3}{|c|}{ How they find cost of the medicines } \\
\hline Easily affordable & 1 & 5.3 \\
\hline Fairly affordable & 2 & 10.5 \\
\hline Expensive & 10 & 52.6 \\
\hline Unaffordable & 6 & 31.6 \\
\hline \multicolumn{3}{|c|}{ Estimated expenditure on medication per month } \\
\hline Mean & \multicolumn{2}{|c|}{$\begin{array}{c}11,321.43(95 \% \text { CI } 8,233.6 \\
14,409.2)\end{array}$} \\
\hline Minimum & \multicolumn{2}{|c|}{6,500} \\
\hline Maximum & \multicolumn{2}{|c|}{25,000} \\
\hline \multicolumn{3}{|c|}{$\begin{array}{l}\text { Child has missed any of their oral medication in the } \\
\text { last } 2 \text { weeks }\end{array}$} \\
\hline Yes & 8 & 42.1 \\
\hline No & 11 & 57.9 \\
\hline \multicolumn{3}{|c|}{ Why the child missed drugs $(n=8)$} \\
\hline $\begin{array}{l}\text { Child got worse } \\
\text { on taking the } \\
\text { medication }\end{array}$ & 1 & 12.5 \\
\hline
\end{tabular}




\begin{tabular}{|c|c|c|}
\hline Variable & Frequency & $\%$ \\
\hline \multicolumn{3}{|c|}{ Why the child missed drugs $(n=8)$} \\
\hline $\begin{array}{l}\text { Could not afford to } \\
\text { buy the medication }\end{array}$ & 4 & 50.0 \\
\hline Forgot & 1 & 12.5 \\
\hline $\begin{array}{l}\text { Others (e.g. could } \\
\text { not find drug) }\end{array}$ & 2 & 25.0 \\
\hline \multicolumn{3}{|c|}{ Number that missed each drug $(n=8)$} \\
\hline Oral methotrexate & 6 & 75.0 \\
\hline $\begin{array}{l}\text { Oral } \\
\text { 6-Mercaptopurine }\end{array}$ & 8 & 100.0 \\
\hline \multicolumn{3}{|c|}{ Number of doses missed Oral methotrexate $(n=6)$} \\
\hline 1 dose & 3 & 50.0 \\
\hline 2 doses & 3 & 50.0 \\
\hline \multicolumn{3}{|c|}{ Oral 6-mercaptopurine $(n=8)$} \\
\hline 1-7 doses & 3 & 37.5 \\
\hline 8-14 doses & 5 & 62.5 \\
\hline \multicolumn{3}{|c|}{$\begin{array}{l}\text { Other form of medication given to the child to man- } \\
\text { age for the disease }\end{array}$} \\
\hline Yes & 2 & 10.5 \\
\hline no & 17 & 89.5 \\
\hline \multicolumn{3}{|c|}{ Other medication given $(n=2)$} \\
\hline Folic & 1 & 50 \\
\hline Wheat grass & 1 & 50 \\
\hline
\end{tabular}

Table 4: Factors affecting adherence

\section{Relationship between adherence to oral chemotherapy and baseline characteristics of the patients}

Various patient variables were cross tabulated with adherence to oral medication using the Fisher's exact test to assess whether there was significant association. There was no significant association between the baseline characteristics and adherence to oral chemotherapy $(\mathrm{P}>0.05)$. However adherence to oral chemotherapy was more in children over ten years of age $(70 \%)$ compared to those less than ten years (44.4\%), (Table 5).

\begin{tabular}{|c|c|c|c|c|}
\hline \multirow{2}{*}{ Variable } & \multicolumn{2}{|c|}{ Adherent to Oral treatment } & Total & P-value \\
\cline { 2 - 5 } & No & Yes & \\
\hline \multicolumn{5}{|c|}{ Sex of the child } \\
\hline Female & $3(50.0 \%)$ & $3(50.0 \%)$ & $3(50.0 \%)$ & 0.506 \\
\hline Male & $5(38.5 \%)$ & $8(61.5 \%)$ & $8(61.5 \%)$ & \\
\hline \multicolumn{5}{|c|}{ BMI categories } \\
\hline Ideal & $6(42.9 \%)$ & $6(42.9 \%)$ & $14(100.0 \%)$ & 0.664 \\
\hline Over/ under & $2(40.0 \%)$ & $2(40.0 \%)$ & $5(100.0 \%)$ & \\
\hline \multicolumn{5}{|c|}{ Child's age } \\
\hline$<10$ & $5(55.6 \%)$ & $4(44.4 \%)$ & $9(100.0 \%)$ & 0.255 \\
\hline$>=10$ & $3(30.0 \%)$ & $7(70.0 \%)$ & $10(100.0 \%)$ & \\
\hline
\end{tabular}

Table 5: Cross tabulation of adherence with patient baseline characteristics

\section{Relationship between adherence and guardian related factors}

The method of acquisition of oral medication, estimated expenditure on medication per month and whether the guardian was counseled on side effects of the medication were found to significantly correlate with adherence ( $\mathrm{P}$ value $0.037,0.02$ and 0.037 respectively). This is as shown in Table 6. 


\begin{tabular}{|c|c|c|c|c|}
\hline \multirow{2}{*}{ Variable } & \multicolumn{2}{|c|}{ Adherent to Oral treatment } & \multirow[t]{2}{*}{ Total } & \multirow[t]{2}{*}{ P-value } \\
\hline & No & Yes & & \\
\hline \multicolumn{5}{|c|}{ Marital status } \\
\hline Single & $2(66.7 \%)$ & $1(33.3 \%)$ & $1(33.3 \%)$ & 0.376 \\
\hline Married & $6(37.5 \%)$ & $10(62.5 \%)$ & $10(62.5 \%)$ & \\
\hline \multicolumn{5}{|c|}{ Occupation } \\
\hline Self Employed & Self Employed & $4(57.1 \%)$ & $7(100.0 \%)$ & 0.663 \\
\hline Unemployed & Unemployed & $7(58.3 \%)$ & $12(100.0 \%)$ & \\
\hline \multicolumn{5}{|c|}{ Average Monthly income } \\
\hline $0-9,999$ & $6(46.2 \%)$ & $7(53.8 \%)$ & $13(100.0 \%)$ & 0.494 \\
\hline Above 10,000 & $2(33.3 \%)$ & $4(66.7 \%)$ & $6(100.0 \%)$ & \\
\hline \multicolumn{5}{|c|}{ Education Level } \\
\hline $\begin{array}{l}\text { Primary and } \\
\text { below }\end{array}$ & $3(37.5 \%)$ & $5(62.5 \%)$ & $5(62.5 \%)$ & 0.551 \\
\hline $\begin{array}{c}\text { Secondary and } \\
\text { above }\end{array}$ & $6(46.2 \%)$ & $7(53.8 \%)$ & $7(53.8 \%)$ & \\
\hline \multicolumn{5}{|c|}{ Counseled on side effects of the medication } \\
\hline yes & $1(12.5 \%)$ & $7(87.5 \%)$ & $8(100.0 \%)$ & 0.037 \\
\hline no & $7(63.6 \%)$ & $4(36.4 \%)$ & $11(100.0 \%)$ & \\
\hline \multicolumn{5}{|c|}{ Counseled by whom } \\
\hline Clinician & $1(33.3 \%)$ & $2(66.7 \%)$ & $3(100.0 \%)$ & 0.375 \\
\hline Nurse & $0(0.0 \%)$ & $5(100.0 \%)$ & $5(100.0 \%)$ & \\
\hline \multicolumn{5}{|c|}{ Medication source-orals } \\
\hline $\begin{array}{l}\text { Hospital } \\
\text { pharmacy }\end{array}$ & $1(20.0 \%)$ & $4(80.0 \%)$ & $5(100.0 \%)$ & 0.267 \\
\hline Private pharmacy & $7(50.0 \%)$ & $7(50.0 \%)$ & $14(100.0 \%)$ & \\
\hline \multicolumn{5}{|c|}{ How they acquire orals medications } \\
\hline $\begin{array}{l}\text { Buys using own } \\
\text { cash }\end{array}$ & $7(63.6 \%)$ & $4(36.4 \%)$ & $11(100.0 \%)$ & 0.037 \\
\hline Others & $1(12.5 \%)$ & $7(87.5 \%)$ & $8(100.0 \%)$ & \\
\hline \multicolumn{5}{|c|}{ How they find cost of the medicines } \\
\hline Affordable & Affordable & $8(61.5 \%)$ & $13(100.0 \%)$ & 0.506 \\
\hline Unaffordable & Unaffordable & $3(50.0 \%)$ & $6(100.0 \%)$ & \\
\hline \multicolumn{5}{|c|}{ Estimated expenditure on medication per month } \\
\hline$<10,000$ & $0(0 \%)$ & $6(100.0 \%)$ & $6(100.0 \%)$ & 0.02 \\
\hline$\geq 10,000$ & $7(87.5 \%)$ & $1(12.5 \%)$ & $8(100.0 \%)$ & \\
\hline
\end{tabular}

NB significant $P$ values are in bold

Table 6: Cross tabulation of adherence with guardian related factors

\section{Prevalence of side effects}

The major (94.7\%) side effect experienced by patients was loss of hair followed by a change in skin/nail pigmentation (73.7\%). Myelosuppression was also observed with $21.1 \%$ having anaemia and $15.8 \%$ having neutropenia. The least observed side effects were dizziness, constipation and tingling sensation of the lower extremities as shown in Table 7.

\begin{tabular}{|c|c|c|}
\hline Side effect & $\begin{array}{c}\text { Frequency } \\
(\mathbf{N}=19)\end{array}$ & Proportions (\%) \\
\hline Vomiting & 12 & 63.2 \\
\hline Diarrhoea & 2 & 10.5 \\
\hline $\begin{array}{c}\text { Hyperacidity/ } \\
\text { stomach ulcers }\end{array}$ & 1 & 5.3 \\
\hline Mouth ulcers & 6 & 31.6 \\
\hline $\begin{array}{c}\text { Tingling sensation } \\
\text { or pain in the lower } \\
\text { extremities }\end{array}$ & 1 & 5.3 \\
\hline
\end{tabular}




\begin{tabular}{|c|c|c|}
\hline Side effect & $\begin{array}{c}\text { Frequency } \\
(\mathbf{N}=19)\end{array}$ & Proportions (\%) \\
\hline Dizziness & 0 & 0 \\
\hline Constipation & 0 & 0 \\
\hline Loss of hair & 18 & 94.7 \\
\hline $\begin{array}{c}\text { Change in skin/nail } \\
\text { pigmentation }\end{array}$ & 14 & 73.7 \\
\hline Anaemia & 4 & 21.1 \\
\hline Neutropenia & 3 & 15.8 \\
\hline Thrombocytopenia & 0 & 0.0 \\
\hline
\end{tabular}

Table 7: Prevalence of side effects

\section{Proportion with appropriate drug use}

It was observed that most of the patients received their parenteral medication at the right dose (89.5-100\%) and right frequency (100\%). As for the oral medication, $63.2 \%$ of the patients received the right dose of 6-Mercaptopurine while majority (68.4\%) of the patients received an under dose of oral methotrexate (Table 8).

\begin{tabular}{|c|c|c|c|c|}
\hline Drug name & Right Dose & Under dose & Over dose & Right Frequency \\
\hline 6-Mercaptopurine & $12(63.2 \%)$ & $7(36.8)$ & $0(0.0 \%)$ & $18(94.7 \%)$ \\
\hline Oral Methotrexate & $5(26.3 \%)$ & $13(68.4 \%)$ & $1(5.3 \%)$ & $19(100 \%)$ \\
\hline $\begin{array}{c}\text { Intrathecal } \\
\text { Methotrexate }\end{array}$ & $19(100 \%)$ & $0(0.0 \%)$ & $0(0.0 \%)$ & $19(100 \%)$ \\
\hline Vincristine & $18(94.7 \%)$ & $1(5.3 \%)$ & $0(0.0 \%)$ & $19(100 \%)$ \\
\hline Doxorubicin & $17(89.5 \%)$ & $1(5.3 \%)$ & $1(5.3 \%)$ & $19(100 \%)$ \\
\hline Cyclophosphamide & $15(78.9 \%)$ & $1(5.3 \%)$ & $3(15.8 \%)$ & $19(100 \%)$ \\
\hline
\end{tabular}

Table 8: Proportion with appropriate drug use

\section{Cumulative doses of doxorubicin used}

It was observed that majority (83.3\%) of the female patients had cumulative doses of doxorubicin of less than $200 \mathrm{mg} / \mathrm{m} 2$, of which most of them were below twelve years of age. In male patients, majority (80\%) of them had cumulative doses of doxorubicin between $200-400 \mathrm{mg} / \mathrm{m} 2$ with most of them being below twelve years (Table 9).

\begin{tabular}{|c|c|c|c|c|}
\hline & \multicolumn{3}{|c|}{ Cumulative doses for doxorubicin } & \multirow[t]{2}{*}{ Totals } \\
\hline & $<200 \mathrm{mg} / \mathrm{m}^{2}$ & $200-400 \mathrm{mg} / \mathrm{m}^{2}$ & $>400 \mathrm{mg} / \mathrm{m}^{2}$ & \\
\hline \multicolumn{5}{|c|}{ Females } \\
\hline$\leq 12$ years & $5(83.3 \%)$ & $1(16.7 \%)$ & $0(0.0 \%)$ & $6(100.0 \%)$ \\
\hline$>12$ years & $0(0.0 \%)$ & $0(0.0 \%)$ & $0(0.0 \%)$ & $0(0.0 \%)$ \\
\hline \multicolumn{5}{|c|}{ Males } \\
\hline$\leq 12$ years & $1(10.0 \%)$ & $8(80.0 \%)$ & $1(10.0 \%)$ & $10(100.0 \%)$ \\
\hline$>12$ years & $0(0.0 \%)$ & $3(100.0 \%)$ & $0(0.0 \%)$ & $3(100.0 \%)$ \\
\hline
\end{tabular}

Table 9: Cumulative doses of doxorubicin

\section{Discussion}

A total of nineteen patients were included in the study of which most of (68.4\%) the patients were male at ( $\mathrm{n}=13)$. This is similar to most studies done in Kenya by Mwanda, et al. and similar studies done in Uganda and Malawi which showed males being more susceptible to the disease than females [9-11].

The mean age of the patients in this study was 9.82 years (95\% CI: 8.3, 11.3) with a minimum age of 4 years and a maximum age of 13 years. In Malawi the peak age was found to be 7.2 years with a range of 4-14 years [11].

A majority of the guardians to the patients had a monthly income of Ksh 0-9,999 which is similar to most caregivers in other developing countries whereby studies done showed that most of the population earned less than 1 US dollar per day [5].

In this study $42.1 \%$ of the patients were found to be non adherent to their oral medication. In a similar study done there was non compliance to oral 6- mercaptopurine of $33.3 \%$ in children with leukemia detected through interviews and a total of 50.3\% non compliance when all other methods of detecting non compliance were included. Another study also showed non adherence in children with cancer at 33\% using laboratory assays of the drugs as a method of detecting non adherence $[12,13]$. 
No statistical association was observed between age and adherence in this study which is similar to a study done where there was no association between age and non-adherence [13]. However a study done by Oliveira, et al. showed age as having an association with non adherence whereby non adherence was more in adolescents than in younger children [12].

The average monthly income earned by the guardians was shown to have no significant association with adherence in this study. These findings were consistent with similar studies which concluded that there was no statistically significant association between non compliance and low per capita family income [11,12]. The level of education and knowledge of the disease of the guardians were also shown to have no statistical significance in relation to adherence which is similar to some studies where demographic factors such as level of education, knowledge of the disease and race were found to have no association with adherence [14]. The lack of statistical association between the various patient characteristics and adherence can be further attributed to the fact that for pediatric patients, adherence is highly dependent on the caregivers of the children. This is shown in various studies where there was better adherence found in the older population excluding the very elderly than in the younger population [15].

Counseling on the side effects of the medication was found to have significant statistical association with adherence (P value 0.037 ) Other studies have shown that non adherers had a less well developed understanding of their illness in terms of prognosis and a less perceived vulnerability especially in the maintenance phase where the patients were asymptomatic. This has been attributed to poor patient counseling and poor doctor to patient communication [16].

How the patients acquire their oral medication was also found to be statistically significant ( $\mathrm{P}$ value 0.037 ). A study done in eleven countries showed marked effects of insurance coverage on adherence whereby very few (8.5\%) were non adherent to their medication due inability to afford treatment since most of them had an insurance cover [17].

The estimated expenditure on medication per month was found to have a significant relationship with adherence in this study(P value 0.02) whereby the minimum amount spent on medication was found to be ksh 6,500 (US \$65) with a maximum of Ksh 25,000 ( US \$250). Other studies done in most developing countries such as Ivory Coast, Malawi and Nigeria showed that the cost of medication and services offered in management of Burkitt's lymphoma ranged from 450 US dollars to 2800 US dollars and since most of the patients were unable to pay for the treatment it led to treatment abdication $[6,18]$.

A majority of the guardians were found to be fairly informed on the disease with the major source of information being from a health care provider. A large number were also aware of the medication the child was taking and duration of treatment in the maintenance phase. However a similar study done in Zambia showed less than $50 \%$ of the caregivers understood the nature of the child's leukemia [19]. This difference can be attributed to the fact that the patients in this study were in the last phase of treatment and therefore the caregivers had a longer time to acquire the information on the disease and its management unlike in the study done in Zambia.

A large number of the patients considered loss of hair as a possible side effect of the medication used followed by vomiting, changes in nail or skin pigmentation and fatigue. A study done in Australia on patient perception of the side effects of cancer chemotherapy also found vomiting, loss of hair and tiredness as the major physical side effects of medication [20].

In this study the most prevalent side effect experienced by the patients was loss of hair (94.7\%), followed by a change in skin/ nail pigmentation $(73.7 \%)$, vomiting (63.2\%), mouth ulcers (31.6\%) and myelosuppression with anaemia being most common (21.1\%). The least observed side effects were dizziness, constipation and tingling sensation of the lower extremities. In a study done by Sitzia, et al. the most common side effects observed using CHOP in management of Non Hodgkin's lymphoma were alopecia with all patients having experienced some hair loss, fatigue was the second most common side effect, followed by nausea, constipation and difficulty in sleeping [21].

In other studies done myelosuppression was also found to be the most prevalent side effect followed by mucositis, vomiting and diarrhea [22,23]. However in this study, myelosuppression is not as prevalent as in most other studies since in this study focus was on the maintenance phase where the doses of cyclophosphamide, adriamycin and methotrexate are not as high as in the other phases of treatment.

Oral methotrexate dosing was found to be inconsistent with some clinicians dosing it at $25 \mathrm{mg} / \mathrm{m}^{2}$ and others at $12.5 \mathrm{mg} / \mathrm{m}^{2} . \mathrm{In}$ various studies done the main dosage used ranged between $15-25 \mathrm{mg} / \mathrm{m}^{2}[8,12,24]$. The drug formulation the drug comes in also poses a problem in that it comes as a tablet formulation of $2.5 \mathrm{mg}$ in the hospital pharmacy and most private pharmacies requiring most of the patients to take 3-16 tablets once every week.

Anthracyclines have been shown to have cardio toxicity which is related to the cumulative dose of the drug used whereby cumulative doses of less than $400 \mathrm{mg} / \mathrm{m}^{2}$ had a $0.14 \%$ risk of causing cardiovascular toxicity and at $550 \mathrm{mg} / \mathrm{m}^{2}$ a risk of $7 \%$ [25-27]. However a study done by Nousianen, et al. found a decrease in left ventricular ejection fraction after a cumulative dose of $200 \mathrm{mg} /$ $\mathrm{m}^{2}$ however, an increase in atrial natriuretic peptide was evident only in cumulative doses of doxorubicin above $400 \mathrm{mg} / \mathrm{m}^{2}[28]$. Various studies have also shown age at treatment to be a risk factor with those below four years being at higher risk. The risk has also been found to be greater in females whereby females especially those above twelve years have been found to have twice as high a risk of early clinical cardio toxicity compared to a male of the same age and body surface area [29]. 
Therefore in our study it can be postulated that $63.1 \%$ of the patients stand a low risk of developing cardio toxicity as their cumulative dosages of doxorubicin are between $200-400 \mathrm{mg} / \mathrm{m}^{2}$ while only a small percentage of the patients (10\%) stand a significant risk of developing cardio toxicity as their cumulative doses are above $400 \mathrm{mg} / \mathrm{m}^{2}$.

\section{Conclusion}

The overall adherence to oral chemotherapy in the management of Non Hodgkin's lymphoma in the maintenance phase was found to be $57.9 \%$. This may contribute to the increased risk of relapse in $42.1 \%$ of the patients who were non adherent.

The commonest reasons given by patients for failing to take their medication were being unable to afford the medication followed by unavailability of the drug in the hospital or private pharmacies.

Method of acquisition of the oral medications and estimated expenditure on medication per month were found to be significant barriers to adherence. This can be attributed to high costs of oral medication especially 6-mercaptopurine.

Counseling on side effects of the medication was also a significant barrier to adherence suggesting that extensive counseling and parent education on medication use and its side effects were lacking.

The major side effects experienced in order of prevalence were alopecia, change in nail or skin pigmentation, vomiting, mouth ulcers and myelosuppression.

A large number of the patients in this study were found to be taking an inadequate dose of their oral methotrexate due to under dosing or improper administration of the drug. Based on cumulative doses of doxorubicin given, it can be postulated that $63.1 \%$ of the patients had a low risk of developing cardiotoxicity while only $10 \%$ had a significant risk of developing cardiotoxicity.

\section{Recommendations}

- Similar studies should be carried out in future using large sample sizes so as to detect important associations that may not have been detected in this study

- Further research should be carried out on event free survival and relapse rate in patients with Non Hodgkin's lymphoma and in the maintenance phase of therapy especially in relation to adherence

\section{References}

1. Cairo SM, Perkins S (2000) Non Hodgkin's lymphoma in children. In : Holland -Frei Cancer medicine ( $5^{\text {th }}$ edn), Bast RC, Kufe WD, Pollock ER, editors. Hamilton, BC Decker, United States.

2. Cool CD, Bitter MA (1997) The malignant lymphomas of Kenya: morphology, immunophenotype and frequency of Epstein-Barr virus in 73 cases. Hum pathol 28: 1026-33.

3. Cardy HA, Sharp L, Little (2001) Burkitt's lymphoma: A review of the epidemiology. Kuwait medical J 33: 293-306.

4. Gioseppe T, Massimiliano B, Cristina T, Bater R, Carli G, et al. (2012) Intensive short term chemotherapy regimen induces high remission rate(over 90\%) and event free survival both in children and adult patients with advanced sporadic Burkitt's Lymphoma/leukemia. Am J Hematol 87: 22-5.

5. Wakabi W (2008) Kenya and Uganda grapple with Burkitt’s lymphoma. Lancet Oncol 9: 319.

6. Plo KJ (2000) Burkitt lymphoma in the Cote D’Ivoire from 1966 to 1995: a progress report. Med Pediatr Oncol 34: 206-9.

7. Spinetta JJ, Masera G, Eden T, Martins AG, Melman JD, et al. (2002) Refusal non compliance and abandonment of treatment in children and adolescents with cancer. Med Pediatr Oncol 38: 114-7.

8. Brecher ML, Sinks FL, Thomas RM (1978) Non-Hodgkin's lymphoma in children. Cancer 41: 1997-2001.

9. Mwanda OW, Rochford R, Moormann AM, Macneil A, Whalen C, et al. (2004) Burkitt's Lymphoma in Kenya: geographical, age, gender and ethnic distribution. East Afr Med J 8: S68-77.

10. Orem J, Mbidde EK, Lambert BO, de Sanjose S, Weiderpas E (2007) Burkitt's lymphoma in Africa a review of the epidemiology and etiology. Afr Health Sci 7: 166-75.

11. Hesseling PB, Broadhead R, Molyneux E, Burgstein E, Schneider JW, et al. (2003) Malawi pilot study of Burkitt's Lymphoma treatment. Med Pediatr Oncol 41: $532-40$.

12. Oliveira BM, Viana MB, Zani CL, Romanha AJ (2004) Clinical and laboratory evaluation of compliance in acute lymphoblastic leukemia. Arch Dis Child 89: $785-8$.

13. Smith SD, Rosen D, Trueworthy, Robert C, Lowman JT (1979) A reliable method of evaluating drug compliance in children with cancer. Cancer $43: 169-73$.

14. Becker MH (1976) Sociobehavioural determinants of compliance In: Compliance with therapeutic regimens. Sacket DL, Haynes RB(ed). Baltimore, John Hopkins university press, United States.

15. Monane M, Bohn RL, Gurwitz JH, Glynn RJ, Levin R, et al. (1996) Compliance with antihypertensive therapy among elderly Medicaid enrollees: the role of age, gender and race. Am J Public Health 86: 1805-8.

16. Stewart M, Brown JB, Boon H, Galajda J, Meredith L, et al. (1999) Evidence on patient-doctor communication. Cancer prev control 3: 25-30.

17. Wang PS, Gilman SM, Guardino M, Christiana JM, Morselli LP, et al. (2000) Initiation and adherence to treatment for mental disorders: examination of patient advocate group members in 11 countries. Med care 38: 926-36.

18. Hasselt VE, Broadhead R (1995) Burkitt's lymphoma: a case file study of 160 patients treated in Queen Elizabeth Central Hospital from1988 to 1992. Pediatr hematol Oncol 12: 277-81. 
19. De Boer JD, Boellaard TN, Parkinson S, Blanchard E, Heij HA (2009) Patient compliance in the treatment of Burkitt's Lymphoma in rural Zambia:A retrospective study on 80 Burkitt's Lymphoma patients in Katete, Zambia. Afr J Paediatr Surg 6: 3-6.

20. Coates A, Abraham S, Kaye SB, Sowerbutts T, Frewin C, et al. (1983) On the receiving end -patient perception of the side effects of cancer chemotherapy. Eur J Cancer Clin Oncol 19: 203-8.

21. Sitzia J, North C, Stanley J, Witerberg N (1997) Side effects of CHOP in the treatment of non-Hodgkin's lymphoma. cancer nursing 20: 430-9.

22. Acquatella G, Insauti CL, Garcia R, Gomez R, Hornandez M, et al. (2004) Outcome of children with B cell Lymphoma in Venezuela with LMB-89 protocol. Pediatr Blood Cancer 43: 580-6.

23. Murphy SB, Hustu OH, Rivera G, Berard CW (1983) End Results of treating children with localized non-Hodgkin's lymphomas with a combined modality approach of lessened intensity. J Clin Oncol 1: 326-30.

24. Lennard L, Welch J, Lilleyman JS (1995) Intracellular metabolites of mercaptopurine in children with lymphoblastic leukemia:a possible indicator of non compliance? Bri J cancer 72: 1004-6.

25. Fischer D, Durivage HJ, Knobf T(1997) In: Cancer chemotherapy handbook ( $5^{\text {th }}$ ed), Baxter S(ed). St Louis Missouri, Mosby, United States.

26. Lipshultz SE, Lipsitz SR, Mone SM, Gorn AM, Sallan SE, et al. (1995) Female sex and higher drug dose as risk factors for late cardiotoxic effects of doxorubicin therapy for childhood cancer. N Engl J Med 332: 1738-44.

27. Von Hoff DD, Layard MW, Basa P, Davis Hl Jr, Von Hoff Al, et al. (1979) Risk factors for doxorubicin induced congestive heart failure. Ann Intern Med 91: 710-7.

28. Nousianen T, Jantinen E, Vanninen E, Remes J, Vuolteenaho O, et al. (1999) Natriuretic peptides as markers of cardiotoxicity during doxorubicin treatment for Non Hodgkin's lymphoma. European journal of haematology 62: 135-41.

29. Silber JH, Jakacki RI, Larsen RL, Goldwein JW, Barber G (1993) Increased risk of cardiac dysfunction after anthracyclines in girls. Med Pediatr Oncol 21: 477-9.

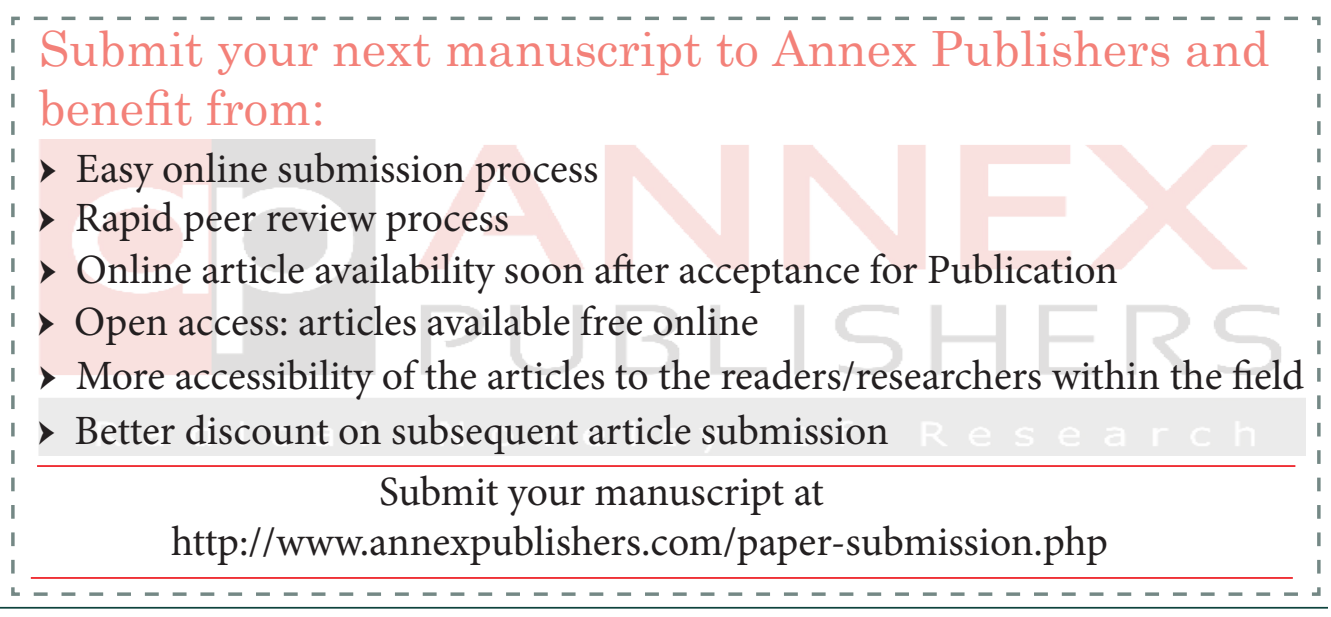

